\title{
Editorial: Employers don't give food; why should they give pensions?
}

In the olden days, before television, radio and avocados, and when there were no human resources, merely master and servant law, employers in many cases were more socially aware than today. When the employer, other than $\mathrm{Mr}$ Gradgrind, saw the employees every day, when the only accountants he had to answer to were his own, and when capitalism was more local than global, the boss felt many times more of an obligation to look after the workforce.

Not in all cases, of course, Dickens and DH Laurence didn't make it all up, but there was a sense of paternalism amongst many employers. And in some cases (for their own interests as well) they even paid or provided employees with other benefits - baths, food, clothing - until the truck acts attempted to avoid exploitation of the workforce where employers offered overpriced goods to captive workers.

The truck acts were successful over time, but as a consequence, most employers paid most employees in cash rather than goods. Today there are exceptions. Employers very often provide a range of benefits - subsidised canteens, cars (sometimes), healthcare and perhaps uniforms. And of course, at least until more recently, pension arrangements of one sort or another.

The critical word is recently. And recently, finance directors of an increasing number of companies have been questioning the cost and purpose of pension arrangements provided by the company. Why, they argue, should companies provide pensions? Why not just increase the salaries by say 10 per cent or 15 per cent and leave the staff to make their own provision? Just think of the savings in time and effort, and the joy of dispensing with the need for trustees and their meetings, investment managers and their excuses and, more acutely nowadays, the interference of the regulatory industry.

One can hardly blame the finance director. Life has become increasingly hard for employers in pensions terms. The accounting rules have perversely done as much, if not more, unnecessary damage to the success story of old age provision in the UK as any other single factor. To require trading companies to provide in their balance a deeply volatile number representing the wind-up costs of pensions on a discontinuance basis, whilst not equally requiring similar wind-up charges of stock-at-fire-sale-valuations, or lease-at-forfeiture-valuations is perverse and unfair and foolish. And not only that, it is misleading to those short-trousered (and increasingly less-well-paid) anoraks known as analysts. But they are the rules currently — at least for defined benefit (DB) schemes. And finance directors find the risk-reward ratio of trying to comply with these curious rules not worth the candle. 
In the meantime there are the 8,000 -odd pages of pensions regulations to find a way through — and the legal advisers to pay to manage it. The regulatory framework of pensions reflects the horror of other areas of disproportionate and counter-productive activity in the UK - particularly in health and safety (where primary-school teachers have to produce risk-assessment reports before they take their charges to the local post-office) and in policing where $\mathcal{f}_{10,000}$ was spent in a successful prosecution of a car driver for eating an apple whilst driving. Common sense in pensions regulation is hard to achieve when a simplification of the law governing the changes of the rules in pension scheme deeds results in ten-fold increase in the length of the regulation from around 33 words to over 3,000 words. There is no advantage in playing the blame game, but someone somewhere ought least to apologise for this.

Add to the accounting rules and the pension rules the rules affecting investments - and the fact that people are living longer - and life becomes all but intolerable. The investment rules imposed by the MFR, and shortly the son-of-MFR, require scheme trustees to invest in less-well performing assets because of their perceived lack of volatility and safety at just the wrong time in the investment cycle. Regulators are almost wholly to blame for this. It is not yet a scandal in the regulatory history of the UK, but the way in which the Financial Services Authority rules insisted on an already pressured Equitable Life insurer to sell equities and the bottom of the cycle and buy bonds when a year later equities had rebounded 30 per cent - almost beggars belief. It helped the regulator - and reduced its risk - but it failed to help those whom the regulator was invented to protect, namely the consumers. In fact, it did them damage.

So finance directors and employers generally are only acting rationally when they try to disavow pension schemes. It is better for them if individuals sort themselves out. After all, there is (or will be) an improved state pension scheme. They can make their own savings and there will be no further claim on the company. They can change jobs without a later claim on the company. And it is all so much simpler.

So is there any future at all for employer-mediated pension arrangements? Some observers are not so sure; they look at the figures, and they look at the risks that are involved, not only for the company but also the reputational risks on the directors of companies if things go wrong, and they predict that the role of companies is set to decline. They have a point - the figures do look unpromising. The question, however, is whether in the long term individuals will have to make their own personal pension arrangements.

There are several responses. One, being explored by the Turner Commission due to report in October 2005, may suggest the introduction of compulsory arrangements perhaps along Australian or Chilean models. There are material drawbacks, most notably political, to such a solution and it will not be an easy one to reach, especially at a time when government may have to raise taxes generally. One solution, slightly drastic, would be to forget secondary or supplementary pensions entirely. People could save, buy a house for renting-out, rely on working till they die, and treat pensions as something rather old-fashioned in a time of ISAs and building society accounts. One solution might be for an education campaign within schools to frighten young children that unless they do 
something about learning the benefits of annuities, the blob will get them.

But all this begs the question whether employer-sponsored pension arrangements are truly dead, or like the Terminator, continue to rise again. Because there still seems to be an appetite among the workforce and the employer to continue to provide retirement arrangements, however perverse in modern conditions that may be. First there is the evidence of our colleagues in the USA and on the continent where attempts continue (and investment managers are convinced they will succeed) to establish company pension systems just as they appear to be biting the dust in the UK.

Why is this so? It is not easy to define. But part of it may be the fact that employees still work a fair number of years for one employer (contrary to popular belief) and employers still feel some form of commitment. It just looks bad to have long-standing employees retiring on hardly anything at all. Secondly, in practice it is all rather difficult for individuals to make proper provision for themselves. Pension schemes involve pooling of risks, hard to do as an individual, and are very different from savings arrangements. Pensions are not savings, they are a form of insurance against living too long. And employers (and trade unions, although they have rarely seized the opportunity in the UK, unlike in, say, Australia) are best (or at least least-worst) placed to arrange pension systems. Insurance companies and other providers are just too expensive and inflexible.

And not only employers want it; employees do too. We can see the degree of industrial unrest now that pensions are being withdrawn. And as the shortage of labour continues, the factors that lead to the growth of pension systems in the mid-fifties have emerged again. The need for employers to recruit and retain are getting worse not easier - and pension arrangements, especially as employees realise how long they are going to live, become ever more important as a need, more than cars and, in the UK, more than healthcare.

So will there be a rebirth of employer-mediated pensions in the UK - and elsewhere in the world? There are signs that it might happen. First, there is the realisation among both the thinking and the drinking classes that the former golden age of secondary pension provision is beginning to come to an end, and that for all but a few the alternatives of: private money, working until the end, income from property or merely savings, is not going to happen. Secondly, there is an appreciation that, for the time being at least, the state is intent on pulling out of mainstream pension provision at any comfortable level. Thirdly, there is a belief that employers will find corporate restructuring easier with a form of pension system in place, especially where age-related retirement may soon be a thing of the past. Next experience of the multinationals where in the rest of the EU corporate pensions are slowly and uncertainly beginning to be established, with increasing employee approval. Then there is likely to be an employee shortage over the next few years as the birth rate persistently stays below the replacement level - it was labour shortages in the past that encouraged the provision of occupational pension schemes several decades ago. Finally, there are likely to be new opportunities as the design of pension arrangements manages to outflank the difficulties of excessive regulation, especially as the opportunities offered by the European Pensions Directive become better understood. 
So it may be that employer-mediated pension arrangements may have a future after all. They are efficient, desired by employers and employees and, most of all, necessary for reasonable survival in old age. Not only that, but government, opposition, think tanks, trade unions and employer organisations - as well as the man in the pub - all want something to happen, and most of all have an idea about what that something might look like. Provided such determination can be mobilised, and it may well be the NAPF and other similar organisations that will co-ordinate it, then we may well see a rebirth of company-sponsored pension schemes in the coming decades. There are of course two questions that we are not quite sure of the answers to. One is quite what form they may take; we can be sure that the existing arrangements are unstable and insupportable. Most likely it will emerge as a form of defined contribution (DC) scheme (to limit the impact of regulation) with some kind of DB objective, which is what most people aspire to and which is riskmanageable. The second issue is whether the parliamentary process can bring itself to accept deregulation, which may mean going back to the olden days. And that may mean accepting that sometimes the system will fail. But we will still have television, radio and avocados.

Robin Ellison

Editor 